\title{
HILGARDIA
}

A Journal of Agricultural Science Published by the California Agricultural Experiment Station

\section{NUTRIENT RESPONSE OF PONDEROSA PINE AND BRUSH SEEDLINGS ON FOREST AND BRUSH SOILS OF CALIFORNIA}

J. VLAMIS, A. M. SCHULTZ, AND H. H. BISWELL 
The nutrient response of seedlings of ponderosa pine, deerbrush, chamise, and western mountain mahogany was studied in pot tests with three types of upland soils taken from the Sierra Nevada and the Coast ranges. The soils were deficient in nitrogen and phosphorus as determined by the growth response of standard agricultural test plants, lettuce and barley. The pine and brush seedlings responded to the addition of nitrogen, except for a few ceanothus plants which were found to have nodules on the root systems. On two of the soils studied the pine and brush seedlings gave little or no response to phosphorus. Seedlings grown in the third soil gave a substantial response to phospharus, and it was established by chemical tests that this soil was of the phosphate-fixing type. There was no significant response to potassium on any of the soils. 


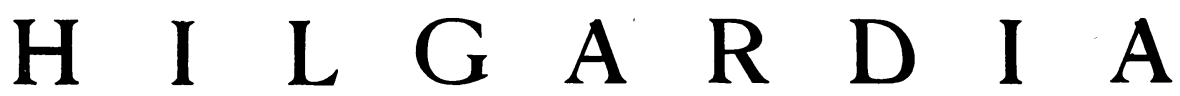

A Journal of Agricultural Science Published by

the California Agricultural Experiment Station

\section{NUTRIENT RESPONSE OF PONDEROSA PINE AND BRUSH SEEDLINGS ON FOREST AND BRUSH SOILS OF CALIFORNIA}

\author{
J. VLAMIS, ${ }^{2}$ A. M. SCHULTZ, ${ }^{3}$ AND H. H. BISWELL ${ }^{4}$
}

\section{INTRODUCTION}

Approximately 40 per cent of the acreage of California supports forest and brush. The soils on this area have been studied little compared with agricultural lands.

This report describes three upland soils and the nutrient responses of seedlings growing on them. The plants used in this study were ponderosa pine (Pinus ponderosa) and three brush species: deerbrush (Ceanothus integerrimus, Lake County form and var. californicus), chamise (Adenostoma fasciculatum), and western mountain mahogany (Cerocacarpus betuloides). The responses of these plants to various nutrient combinations were compared with those of two standard test plants-Romaine lettuce and barley.

\section{MATERIALS AND METHODS}

Pine and brush seedlings were planted in 10-inch pots painted on the inside with black asphalt paint to avoid contamination. Each pot received 6,400 grams of soil and was planted to five seedlings. One set of pots without any fertilizer added was kept as a control. Another set received the full combination of nitrogen $(\mathrm{N})$, added as ammonium nitrate, phosphorus $(\mathrm{P})$, added as monobasic calcium phosphate, and potassium (K), added as potassium sulfate. The rates applied were 200 pounds $\mathrm{N}, 300$ pounds $\mathrm{P}_{2} \mathrm{O}_{5}$, and 200 pounds $\mathrm{K}_{2} \mathrm{O}$ per acre. Then, other pots were set up, consisting of $\mathrm{P}+\mathrm{K}$, $\mathrm{N}+\mathrm{K}$, and $\mathrm{N}+\mathrm{P}$, giving a total of five treatments. Chemically pure salts in solution were mixed throughout the soil, and each treatment was set up in triplicate.

${ }^{1}$ A part of this study was conducted coöperatively by the University of California and the California Department of Fish and Game under Federal Aid in Wildlife Restoration Act Project California 51-R. Agricultural Experiment Station projects were 1360 and H-1157. Received for publication May 27, 1958.

${ }^{2}$ Associate Soil Chemist in Soils and Plant Nutrition in the Experiment Station, Berkeley.

${ }^{3}$ Specialist in the School of Forestry, Berkeley.

${ }^{4}$ Professor of Forestry and Plant Ecologist in the Experiment Station, Berkeley. 
This system of fertility testing, known as a modified Mitscherlich technique, has been used with Romaine lettuce as a test plant, on a large number of agricultural soils in California. The data have been correlated with field experiments and, when plotted graphically, provide curves which can be used to predict probable field response to soil fertilization (Jenny et al., 1950).

The seeds of ponderosa pine, obtained from Hoberg's in Lake County, were germinated in sand flats and transplanted as seedlings to pots of the soil being tested. Deerbrush seedlings were transplanted from the field; while mountain mahogany and chamise seeds were germinated in sand flats, as was pine.

Lettuce and barley plants were grown in 6-inch pots containing 1,600 grams of soil each. Lettuce was planted as 3-week-old seedlings, one in each of triplicate pots, while the barley was planted as seed in duplicate pots of five plants each.

The lettuce and barley were grown in the greenhouse, while the pine and brush seedlings were grown outdoors alongside the greenhouse. All plants were supplied with distilled water as needed. The outdoor plants were protected from rainfall by overhead plastic sheets.

After a growth period indicated in each experiment, the pine and brush seedlings were harvested and oven dry weights obtained. In some cases, the roots were washed free of soil and likewise dried and weighed. The lettuce and barley plants were grown for a period of six weeks before harvesting. The dry weights were used as a basis for comparing the nutrient response.

\section{Description of Soils}

One of the soils used in these tests is classified as a Holland loam soil. It was obtained from the Teaford Forest in the Sierra Nevada of Madera County at an elevation of 3500 feet. The area supports a good stand of ponderosa pine associated with black oak (Quercus kelloggii) and incense cedar (Libocedrus decurrens), with an understory of shrubs and herbs.

The Holland series is extensive in the Sierra Nevada foothills and occurs in the Coast Range and the mountain areas of southern California. It is derived from granitic parent material and occurs in areas with a rainfall of 30 to 60 inches. The vegetation consists largely of pine, ponderosa pine predominating at the higher altitudes, and digger pine ( $P$. sabiniana), oaks, and shrubs at the lower elevations.

The second soil tested is a Salminas loam, collected at Hoberg's in Lake County, situated at an elevation of 3000 feet in the Coast Range. This site supports ponderosa pine associated with sugar pine ( $P$. lambertiana), Douglas Fir (Pseudotsuga menziesii), some shrubs, and few herbaceous plants.

The Salminas series which is formed in place on andesite occurs under a mean annual rainfall of 30 to 60 inches. This is a newly established series, mapped in the volcanic areas of the central and north Coast Ranges and in the Cascades.

The third soil studied is Maymen, taken from the upper slopes of Cow Mt. in Lake County. The vegetation consists of such shrubs as chamise

\footnotetext{
"See "Literature Cited" for eitations referred to in the text by author and date.
} 
(Adenostoma fasciculatum), manzanitas (Arctostaphylos spp.), and scrub oak (Quercus dumosa).

The Maymen series is found in the Coast Range of California. It is characteristically shallow and stony in contrast to the Holland and Salminas soils. Maymen soil is found typically on steep slopes, is light or pale brown, and is formed on well-consolidated sandstone, shale, or conglomerate. Annual rainfall ranges from 25 to 40 inches (Storie and Weir, 1953).

A further description of these soils and their exchangeable base status is given in Table 1.

TABLE 1

CHEMICAL ANALYSIS AND PEDOLOGICAL DESCRIPTION OF HOLLAND, SALMINAS, AND MAYMEN SOILS*

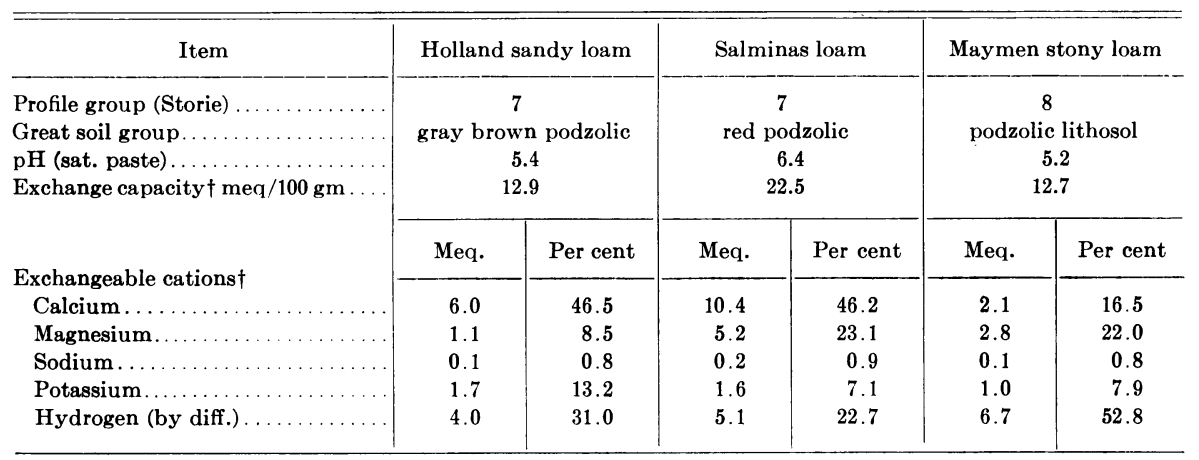

${ }^{*}$ Laboratory analysis performed by M. Gitlitz, Department of Soils and Plant Nutrition, Berkeley.

+ Based on $2 \mathrm{~mm}$ and smaller fraction of soil. Data reported as meq. per $100 \mathrm{gms}$ of sieved material.

\section{Experimental Results}

Holland Soil. The weights of the tops of ponderosa pine, deerbrush, lettuce and barley plants grown in the Holland soil are shown in Figure 1. The variability within each treatment encountered in these experiments with ponderosa pine is indicated in Table 2. Also included in this table are the root/shoot ratios calculated from the average dry weights of each treatment. Height and stem diameter measurements of the pine seedlings just prior to harvesting are given in Table 3.

In the course of the first season's growth of the deerbrush seedlings, it became apparent that in the minus-nitrogen treatment, one seedling was much larger than the others in the same pot. When the roots of this large seedling were washed free of soil, they were found to include a very large nodule. However, since only one plant out of 75 in this experiment exhibited this structure, no particular significance was attached to it.

In a subsequent experiment, when deerbrush seedlings were grown for two seasons, a larger incidence of nodules appeared on the roots. One seedling stood out among the rest in the minus-nitrogen treatment, and four were conspicuous in the check pots where no fertilizer had been added. After washing the roots, it was found that these larger plants contained one or more large nodules, while the smaller plants had numerous, minute nodules. 


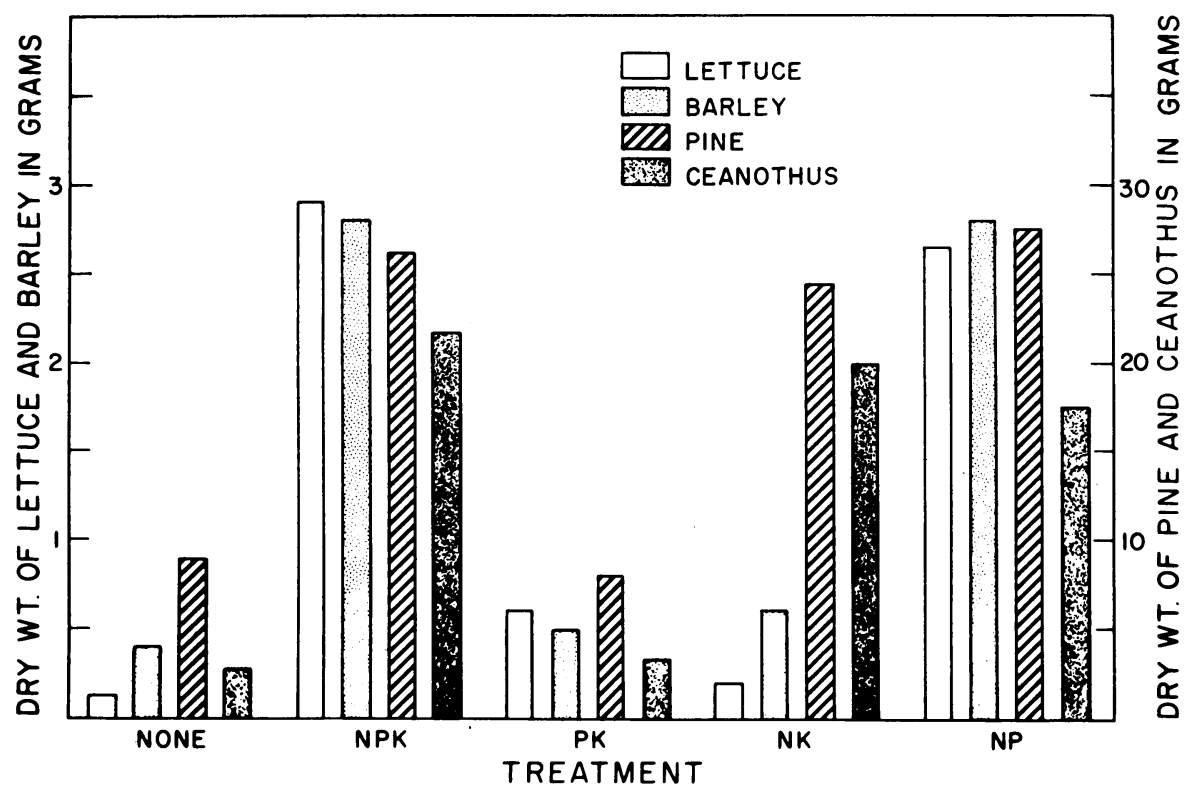

Fig. 1. Dry weights of pine, deerbrush (ceanothus), lettuce, and barley shoots grown in Holland sandy loam fertilized with combinations of nitrogen, phosphorus, and potassium.

TABLE 2

AVERAGE DRY WEIGHTS OF FIVE PONDEROSA PINE SEEDLINGS IN EACH OF THREE POTS PLANTED IN HOLLAND SOIL JUNE, 1955, AND HARVESTED JUNE, 1956

\begin{tabular}{|c|c|c|c|c|c|c|c|c|c|}
\hline \multirow{2}{*}{$\begin{array}{c}\text { Nutrient } \\
\text { combinations }\end{array}$} & \multicolumn{4}{|c|}{ Shoots } & \multicolumn{4}{|c|}{ Roots } & \multirow{2}{*}{$\begin{array}{l}\text { Root } \\
\text { shoot } \\
\text { ratio }\end{array}$} \\
\hline & (1) & (2) & (3) & Average & (1) & (2) & (3) & Average & \\
\hline & $g m s$ & $g m s$ & $g m s$ & $g m s$ & $g m s$ & $g m s$ & $g m s$ & $g m s$ & \\
\hline Check. & 9.2 & 9.2 & 9.1 & 9.2 & 6.7 & 7.7 & 9.0 & 7.8 & 0.85 \\
\hline NPK. & 25.1 & 21.5 & 31.9 & 26.2 & 10.9 & 11.9 & 13.1 & 12.0 & 0.46 \\
\hline PK.. & 7.8 & 7.7 & 7.8 & 7.8 & 6.7 & 5.1 & 8.9 & 6.9 & 0.88 \\
\hline NK. & 23.8 & 23.7 & 25.6 & 24.4 & 10.4 & 12.0 & 10.6 & 11.0 & 0.45 \\
\hline NP...... & 28.6 & 23.0 & 29.1 & 26.9 & 13.5 & 10.5 & 10.4 & 11.5 & 0.43 \\
\hline
\end{tabular}

TABLE 3

PHYSICAL MEASUREMENTS OF PONDEROSA PINE SEEDLINGS GROWN IN HOLLAND SOIL

\begin{tabular}{|c|c|c|c|}
\hline Nutrient combinations & $\begin{array}{c}\text { Stem } \\
\text { diameter }\end{array}$ & $\begin{array}{l}\text { Height of } \\
\text { growing point }\end{array}$ & $\begin{array}{l}\text { No. of } \\
\text { laterals }\end{array}$ \\
\hline & $m m$ & inches & number \\
\hline Check. & $3.5 \pm .1$ & $3.4 \pm .1$ & $4.4 \pm .2$ \\
\hline NPK. & $4.8 \pm .2$ & $5.0 \pm .2$ & $4.4 \pm .2$ \\
\hline PK... & $3.1 \pm .1$ & $3.2 \pm .1$ & $3.8 \pm .2$ \\
\hline NK. . & $4.6 \pm .2$ & $5.1 \pm .2$ & $4.6 \pm .4$ \\
\hline $\mathrm{NP} \ldots \ldots \ldots \ldots \ldots$ & $4.5 \pm .1$ & $5.0 \pm .2$ & $4.3 \pm .3$ \\
\hline
\end{tabular}


The dry weights of the shoots and roots of deerbrush after two seasons' growth are given in Table 4 . For the sake of clarity in comparing the response to added nutrients, the weights of nodulated seedlings are omitted from the averages. Thus, if two seedlings had nodules in a given pot, the weights of the remaining three were combined and adjusted to a per-pot

TABLE 4

DRY WEIGHTS OF FIVE DEERBRUSH SEEDLINGS PER POT PLANTED

IN HOLIAAND SOIL JUNE, 1955, AND HARVESTED JUNE, 1957

\begin{tabular}{|c|c|c|c|c|c|c|c|c|c|}
\hline \multirow{2}{*}{$\begin{array}{c}\text { Nutrient } \\
\text { combinations }\end{array}$} & \multicolumn{4}{|c|}{ Shoots } & \multicolumn{4}{|c|}{ Roots } & \multirow{2}{*}{$\begin{array}{l}\text { Root/ } \\
\text { shoot } \\
\text { ratio }\end{array}$} \\
\hline & (1) & (2) & (3) & Average & (1) & (2) & (3) & Average & \\
\hline & $g m s$ & $g m s$ & $g m s$ & $g m s$ & $g m s$ & $g m s$ & $g m s$ & $g m s$ & \\
\hline Check & 3.4 & $3.7^{*}$ & $2.3^{*}$ & 3.1 & 4.5 & $3.5^{*}$ & $2.0^{*}$ & 3.3 & 1.06 \\
\hline NPK. . & 49.6 & 60.3 & 55.1 & 55.0 & 29.2 & 48.0 & 44.6 & 40.6 & 0.74 \\
\hline PK.. & $2.9^{*}$ & 3.1 & 3.7 & 3.2 & $2.6^{*}$ & 5.5 & 5.5 & 4.5 & 1.41 \\
\hline NK. & 44.8 & 41.9 & 48.2 & 45.0 & 37.3 & 31.9 & 35.4 & 34.9 & 0.78 \\
\hline $\mathrm{NP}$. & 49.6 & 48.8 & 51.9 & 50.1 & 44.5 & 31.7 & 42.1 & 39.4 & 0.79 \\
\hline
\end{tabular}

* Pot averages calculated from weights of plants without nodules. See Table 5 for detailed data.

TABLE 5

I) RY WEIGHTS IN GRAMS OF EACH SHOOT FOUND IN POTS CONTAINING NODULATED DEERBRUSH GROWN IN HOLLAND SOIL

\begin{tabular}{|c|c|c|c|c|c|c|}
\hline \multirow{2}{*}{\multicolumn{2}{|c|}{ Treatment pot no. }} & \multicolumn{5}{|c|}{ Individual plants } \\
\hline & & (1) & (2) & (3) & (4) & (5) \\
\hline \multirow[t]{3}{*}{ Check } & 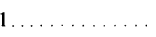 & 0.72 & 0.50 & 0.56 & 0.83 & 0.81 \\
\hline & 2. & 0.78 & 0.83 & 0.60 & $\underline{4.83}$ & $\underline{6.61}^{*}$ \\
\hline & 3. & 0.61 & 0.43 & 0.32 & $\underline{4.14}$ & $\underline{5.86}$ \\
\hline \multirow[t]{3}{*}{$\mathrm{PK}$} & $1 \ldots$ & 1.13 & 0.60 & 0.44 & 0.12 & $\underline{5.19}$ \\
\hline & 2. & 0.74 & 0.58 & 0.71 & 0.46 & 0.59 \\
\hline & 3. & 0.40 & 0.83 & 0.66 & 0.96 & 0.84 \\
\hline
\end{tabular}

* Underlined figures represent plants found to have large nodules on roots.

basis by multiplying by $5 / 3$. In the last column are shown the root/shoot ratios in each treatment.

The comparison of seedling weights according to the presence or absence of nodules is shown in Table 5 and illustrated in Figure 2.

The results obtained on the Holland soil may be summarized as follows. According to the standard lettuce and barley test, this soil is acutely deficient in nitrogen and phosphorus. The ponderosa pine seedlings responded distinctly to the addition of nitrogen, but grew almost as well when phosphorus was omitted as when it was included. Photographs of the pine and brush are shown in Figure 3. 


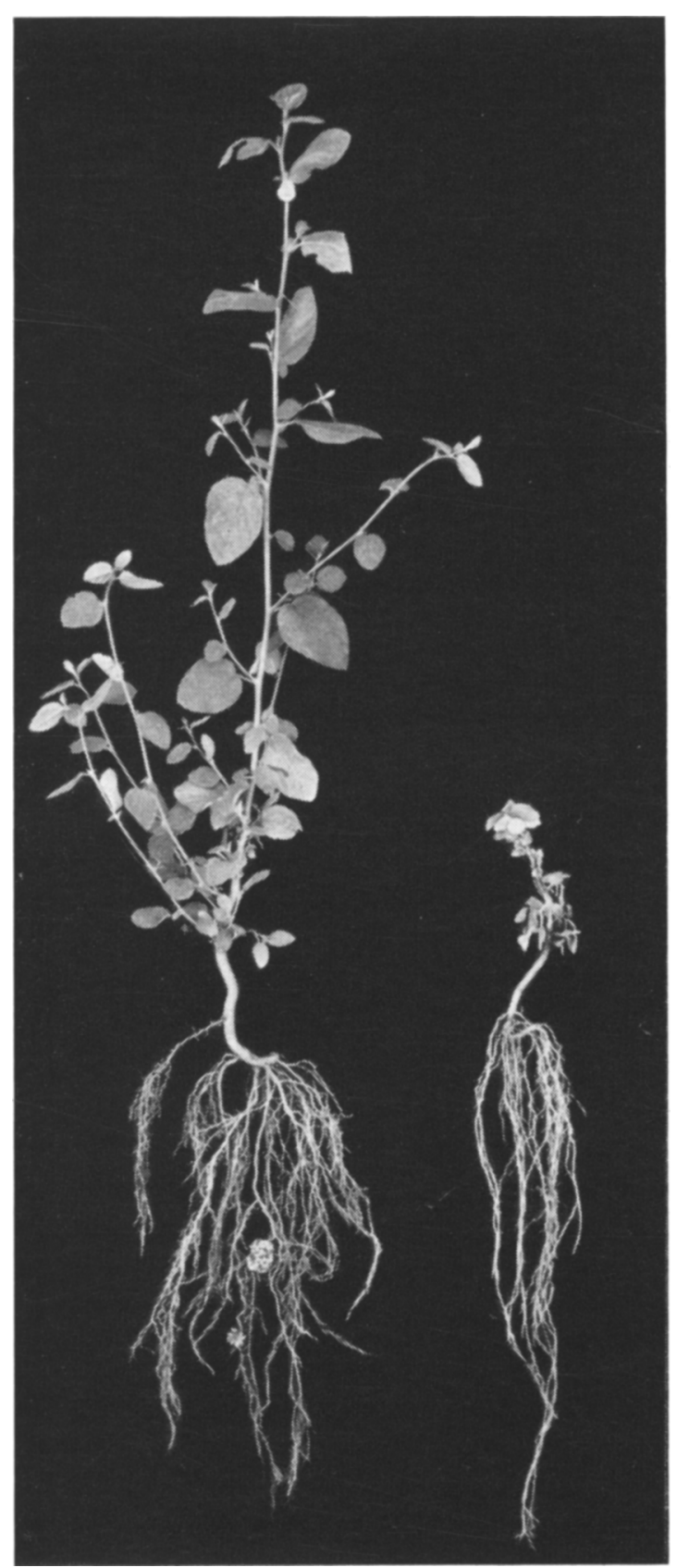

Fig. 2. Deerbrush plants grown in the same pot of Holland sandy loam fertilized with phosphorus and potassium. Nitrogen was not added. Plant on the left with nodules outgrew the plant without nodules by eight times. 
After one season's growth, deerbrush behaved in the same manner as the pine seedlings, that is, strong response to added nitrogen, slight response to phosphorus. After two seasons' growth, some deerbrush plants not supplied with nitrogen gave indications of acquiring an independent nitrogen supply, and this was correlated with the presence of large nodules on the roots.
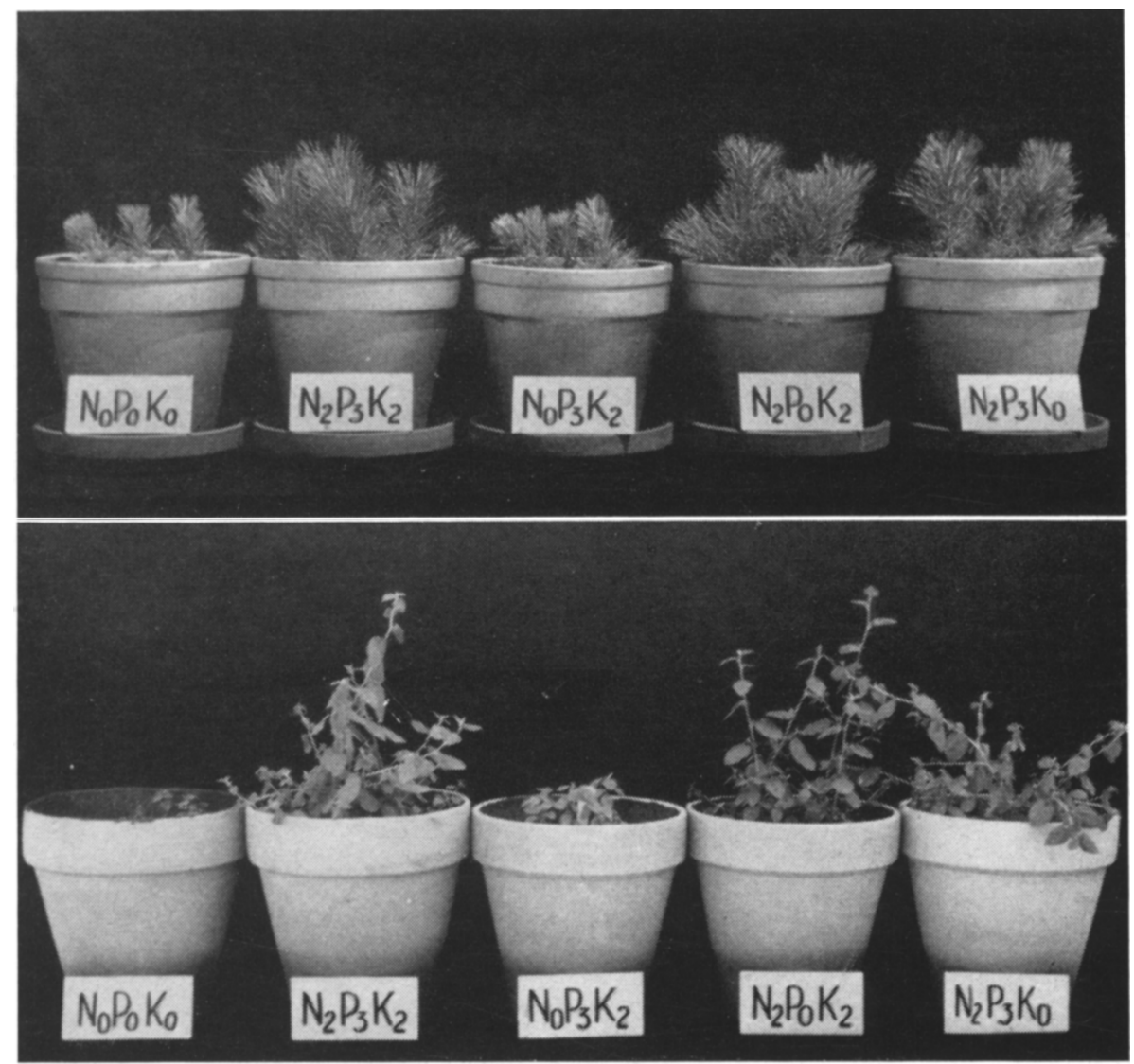

Fig. 3. Pine and deerbrush seedlings growing in 10-inch pots of Holland sandy loam fertilized with combinations of nitrogen, phosphorus, and potassium.

This soil appeared to be adequately supplied with potassium to satisfy the requirements of lettuce, barley, pine, and deerbrush.

Salminas Soil. The shoot yields obtained from the growth of pine, deerbrush, lettuce, and barley on the Salminas soil are summarized graphically in Figure 4. The weights of top and root produced in each pot are given in Table 6 for ponderosa pine, and in Table 7 for deerbrush.

There was no indication of nitrogen fixation by the deerbrush seedlings in this soil and examination of the roots did not reveal the presence of nodules. However, these plants were grown for only one season on this soil. 
On the Holland soil, nodule formation became prominent during the second growing season. It is also possible, although not likely, that varietal differences may exist with respect to nodulation. The Salminas soil was planted to the Lake County form of deerbrush while the Holland soil was planted to variety californicus, commonly found in the Sierra Nevada foothills. In other words, the soils were planted to the seedlings obtained from their respective natural environments.

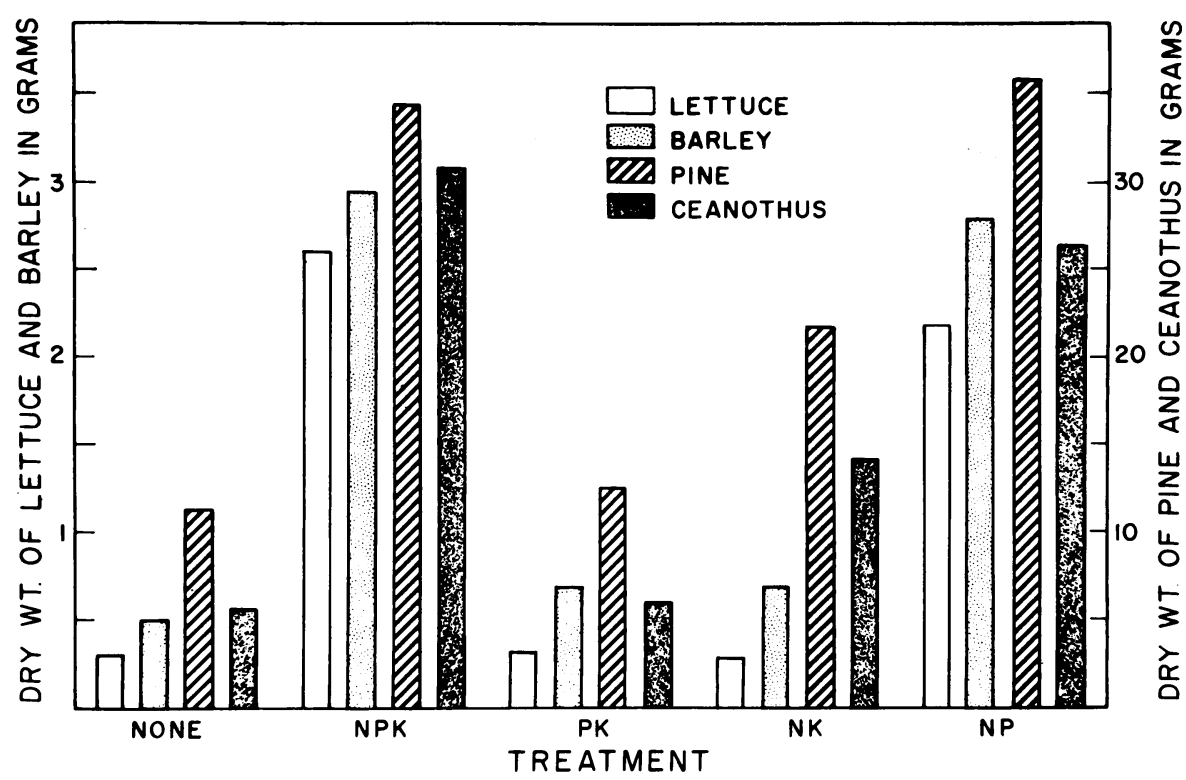

Fig. 4. Dry weights of pine, deerbrush (ceanothus), lettuce, and barley shoots grown in Salminas loam fertilized with combinations of nitrogen, phosphorus, and potassium.

The lettuce and barley show the Salminas soil to be severely deficient in nitrogen and phosphorus. In fact, the fertilizer responses of these plants on both the Holland and Salminas soils are remarkably similar. However, a differentiation appears between the two soils when the pine and deerbrush yields are examined. While both species show strong nitrogen responses in the two soils, there was a larger phosphorus response in the Salminas soil. Yet, the lettuce and barley response to this nutrient was of about the same magnitude in both soils.

This discrepancy may be explained, to a large extent, by the different nature of the two soils. A laboratory test of phosphorus availability to plants, known as the Truog method (Truog, 1930), is widely used in agricultural research. This test was applied to the Holland and Salminas soils at several levels of added phosphorus. The amounts of phosphorus extracted at each level are given in Figure 5. The curves indicate the Salminas soil to be of the phosphate-fixing type, while the Holland soil has higher available phos- 
phate for each increment added. Thus, the pine and deerbrush are able to distinguish by a growth response between two phosphate deficient soils, one of the phosphate-fixing type, the other of the nonfixing type. On the other hand, lettuce and barley, being more sensitive to phosphorus deficiency, are unable to separate these soils as to phosphorus supply.

There was no apparent response to potassium by any of the plants grown on this soil.

TABLE 6

J) WY WEIGHTS OF FIVE PONDEROSA PINE SEEDLINGS PER POT PIANTEI) IN SALMINAS SOIL JUNE, 1956, AND

HARVESTED JULY, 1957

\begin{tabular}{|c|c|c|c|c|c|c|c|c|c|}
\hline \multirow{2}{*}{$\begin{array}{c}\text { Nutrient } \\
\text { combinations }\end{array}$} & \multicolumn{4}{|c|}{ Shoots } & \multicolumn{4}{|c|}{ Roots } & \multirow{2}{*}{$\begin{array}{l}\text { Root/ } \\
\text { shoot } \\
\text { ratio }\end{array}$} \\
\hline & (1) & (2) & (3) & Average & (1) & (2) & (3) & Average & \\
\hline & $g m s$ & $g m s$ & $g m s$ & $g m s$ & $g m s$ & $g m s$ & $g m s$ & $g m s$ & \\
\hline Check. & 13.0 & 10.8 & 10.4 & 11.4 & 10.6 & 7.8 & 7.8 & 8.7 & 0.76 \\
\hline NPK. & 35.2 & 35.0 & 33.3 & 34.5 & 21.6 & 20.8 & 14.4 & 18.9 & 0.55 \\
\hline PK. & 12.0 & 10.2 & 15.6 & 12.6 & 11.2 & 8.0 & 11.8 & 10.3 & 0.82 \\
\hline NK. & 22.2 & 24.2 & 19.0 & 21.8 & 14.8 & 15.8 & 9.0 & 13.2 & 0.61 \\
\hline NP. & 37.6 & 37.6 & 32.6 & 35.9 & 26.4 & 25.6 & 21.7 & 24.6 & 0.69 \\
\hline
\end{tabular}

TABLE 7

DRY WEIGHTS OF FIVE DEERBRUSH SEEDLINGS PER POT PLANTED

IN SALMINAS SOIL JUNE, 1956, AND HARVESTED SEPTEMBER, 1956

\begin{tabular}{|c|c|c|c|c|c|c|c|c|c|}
\hline \multirow{2}{*}{$\begin{array}{c}\text { Nutrient } \\
\text { combinations }\end{array}$} & \multicolumn{4}{|c|}{ Shoots } & \multicolumn{4}{|c|}{ Roots } & \multirow{2}{*}{$\begin{array}{c}\text { Root/ } \\
\text { shoot } \\
\text { ratio }\end{array}$} \\
\hline & (1) & (2) & (3) & Average & (1) & (2) & (3) & Average & \\
\hline & $g m s$ & $g m s$ & $g m s$ & $g m s$ & $g m s$ & $g m s$ & $g m s$ & $g m s$ & \\
\hline Check. & 2.6 & 3.0 & 2.9 & 2.8 & 3.2 & 3.3 & 3.2 & 3.2 & 1.14 \\
\hline PK... & 2.6 & 3.6 & 2.7 & 3.0 & 1.8 & 3.2 & 1.9 & 2.3 & 0.77 \\
\hline NK & 6.9 & 7.0 & 7.8 & 7.2 & 6.3 & 6.4 & 7.9 & 6.9 & 0.96 \\
\hline NP. & 10.3 & 16.6 & 13.1 & 13.3 & 7.8 & 11.4 & 9.9 & 9.7 & 0.73 \\
\hline
\end{tabular}

Maymen Soil. This soil was tested with western mountain mahogany, chamise, lettuce, and barley. Pine was not included since Maymen soil supports primarily a cover of brush vegetation. The shoot weights of the plants grown on this soil are shown in Figure 6. Root weights were not obtained.

As in the other two soils, acute deficiencies in nitrogen and phosphorus were found in the Maymen soil as measured by lettuce and barley. The brush seedlings responded distinctly to the addition of nitrogen and only slightly to phosphorus. There was no evidence of a potassium response by any of the plants used in this test. (See Figure 7.) 


\section{DISCUSSION}

The mineral nutrition of forest trees and brush plants is assuming greater significance as land utilization becomes more intensive. A major role in this field is being assumed by soil fertilization studies carried out in greenhouses,

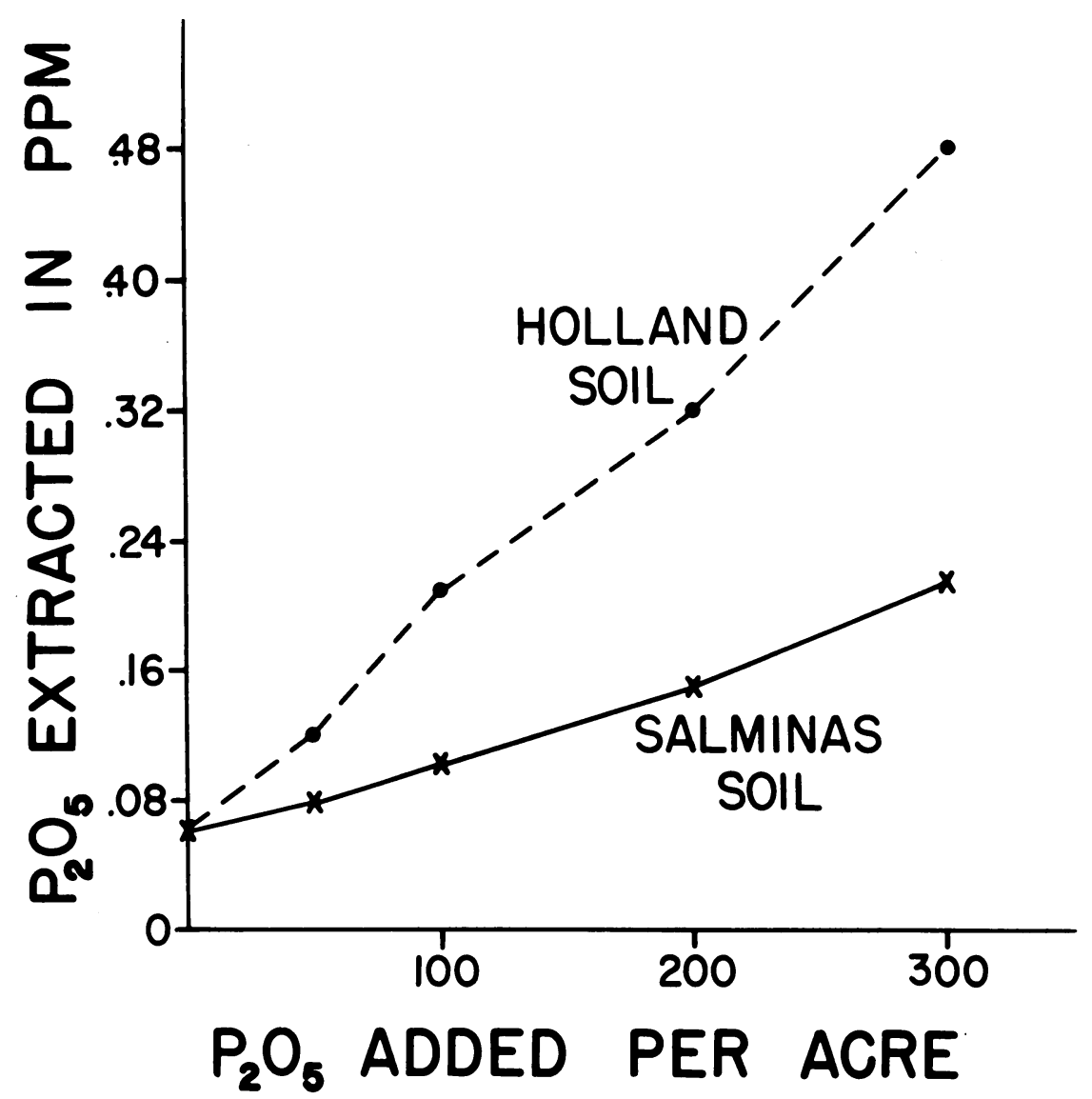

Fig. 5. Phosphate extracted by Truog method from Holland sandy loam and Salminas loam treated with several rates of monobasic calcium phosphate.

nurseries and in the forest. Growth responses to nitrogen applications have been encountered on such diversified plants and areas as loblolly pine in North Carolina (Rosendahl and Korstian, 1945), Douglas fir in Washington (Gessel and Walker, 1956), and brush plants in southern California (Hellmers, et al., 1955; Vlamis, et al., 1954). Likewise, improved growth from added phosphate has been obtained on black locust and green ash in Iowa (McComb and Kapel, 1942), and in Australia with Monterey pine (Boomsma, 1949) and slash and loblolly pines (Richards, 1956). Potassium deficiency has been corrected on pines and spruces in New York both by 
soil fertilization (Heiberg and White, 1951) and more recently by aerial applications (White, 1956). Where adequate nutrient conditions exist in the soil, no response at all has been obtained with pine trees in nursery plantings (Hansen, 1923). In addition to its effect in promoting growth, soil fertilization has been used to increase cone and seed production (Allen, 1953; ('handler, 1938).

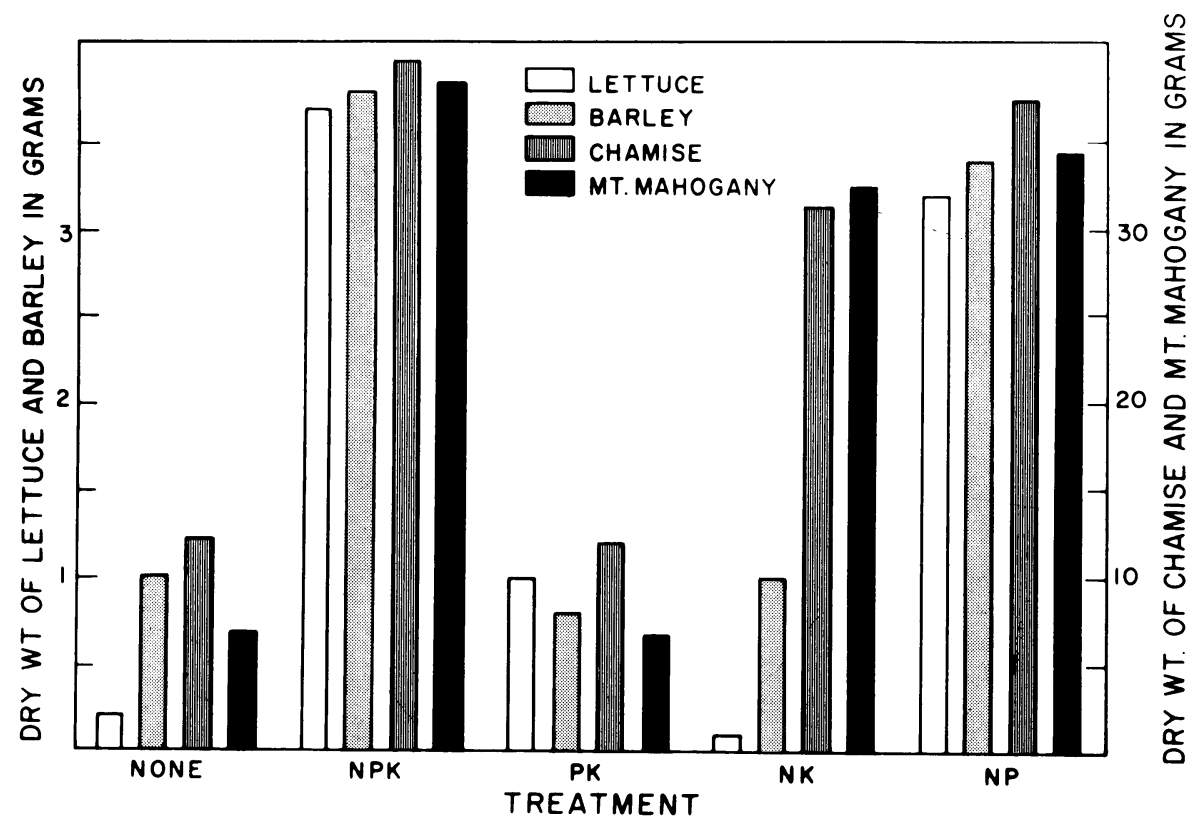

Fig. 6. Dry weights of chamise, mountain mahogany, lettuce, and barley shoots grown in Maymen stony loam fertilized with combinations of nitrogen, phosphorus, and potassium.

The results of this study showed that seedlings of ponderosa pine and brush responded strongly to nitrogen fertilization on all three soils and in the same order of magnitude as lettuce and barley. The only exception to this response appeared when some deerbrush plants developed root nodules and grew as though they had acquired an independent nitrogen supply in the manner common to legumes. The occurrence of nodules has been observed on the roots of several species of ceanothus growing in the field (Quick, 1934). Bacteria have been isolated from nodules of ceanothus, and when grown in pure culture were eapable of fixing nitrogen (Bottomley, 1915).

The plants bearing nodules were larger than those without them but were still noticeably smaller than those supplied with ammonium nitrate. This may be accounted for by the fact that the former plants did not develop nodules until the second year, while the latter were supplied with nitrogen from the start.

The phosphorus supply of these soils was determined to be extremely low according to the lettuce and barley test. In other words, by agricultural 
standards many crops would be expected to respond to applications of phosphorus. Yet, on two of these soils the response to this nutrient by pine and brush seedlings was slight or insignificant. Even on the third soil, shown by laboratory test to be a phosphate fixer, the response of pine and brush was moderate compared with that of lettuce and barley. The comparative re-
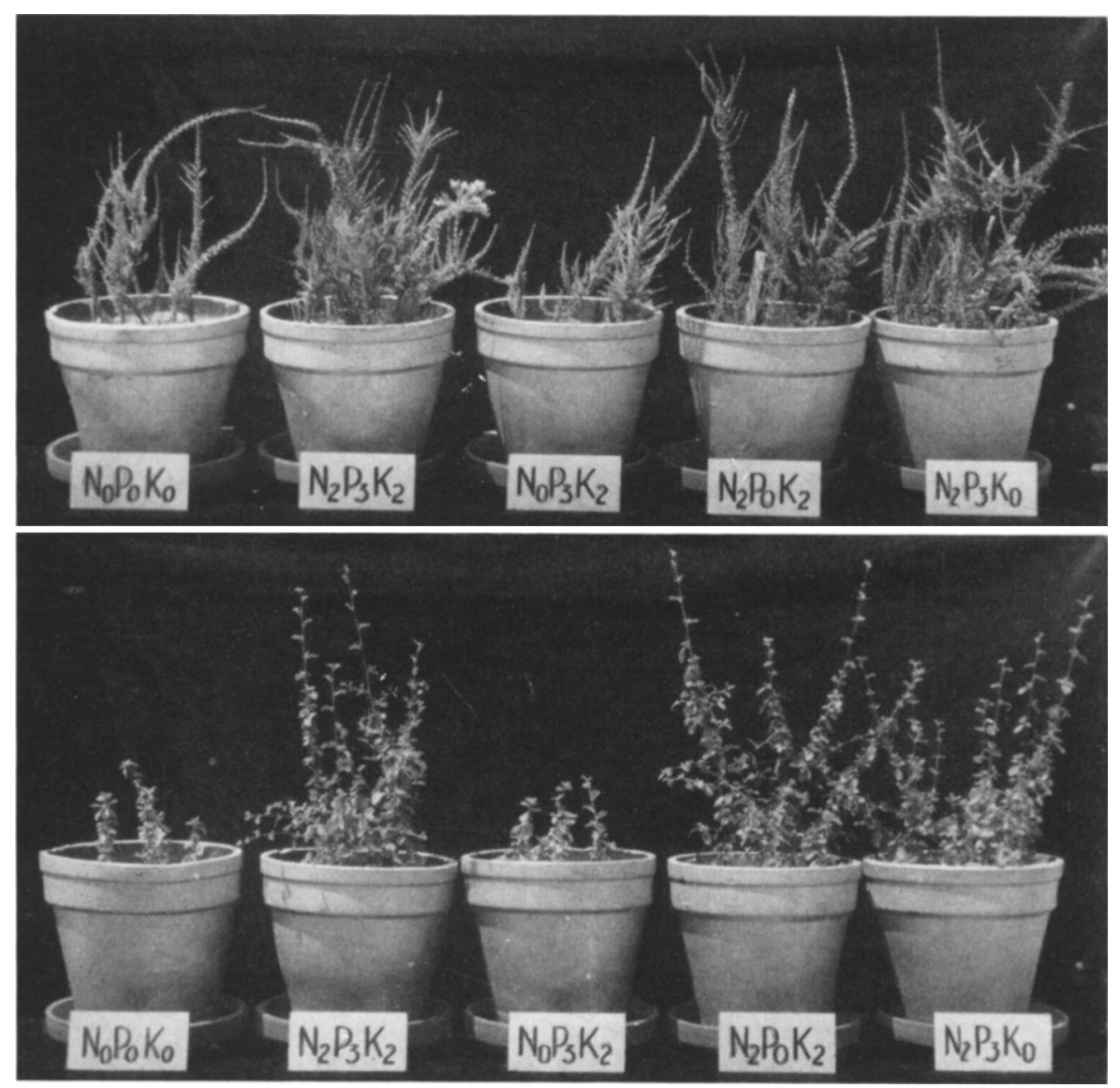

Fig. 7. Two-year-old chamise (upper) and mountain mahogany seedlings (lower) growing in 10-inch pots of Maymen stony loam fertilized with nitrogen, phosphorus, and potassium.

sponse to each nutrient combination by each species for the three soils is shown in Table 8, where the relative values are given based on a 100 per cent rating for the complete treatment.

The differential response to phosphorus by agricultural and forest crops has been studied by Rennie (1955), who estimates that phosphorus uptake is greatest by agricultural crops, followed in decreasing order by hardwoods, most conifers, and pines. Likewise, many vegetational patterns of Australia have been related by Beadle (1954) to the phosphate level of the soil. 
The specific response of these plants to nutrient supply or fertilization offers a nutritional approach to manipulation of vegetation and a possible explanation of patterns of plant distribution arising from soil fertility characteristics and plant reaction to them.

Ponderosa pine and brush seedlings would seem to be better adapted than grass to grow on soil deficient in phosphorus. This relationship could be ex-

TABLE 8

RELATIVE NUTRIENT RESPONSE OF PINE, DEERBRUSH, CHAMISE, AND WESTERN MOUNTAIN MAHOGANY SEEDLINGS, AND LETTUCE AND BARLEY PLANTS

\begin{tabular}{|c|c|c|c|c|}
\hline \multirow{2}{*}{ Nutrient combinations } & \multicolumn{4}{|c|}{ Per cent of NPK yields } \\
\hline & Pine & Deerbrush & Lettuce & Barley \\
\hline & \multicolumn{4}{|c|}{ Holland sandy loam } \\
\hline Check. & 35 & $12^{*}$ & 4 & 14 \\
\hline NPK. & 100 & 100 & 100 & 100 \\
\hline PK. & 30 & $15^{*}$ & 21 & 18 \\
\hline NK. & 93 & 93 & 7 & 22 \\
\hline \multirow[t]{2}{*}{ NP. } & 103 & 81 & 91 & 100 \\
\hline & \multicolumn{4}{|c|}{ Salminas loam } \\
\hline Check. & 33 & 18 & 12 & 17 \\
\hline NPK. . & 100 & 100 & 100 & 100 \\
\hline PK... & 37 & 19 & 12 & 24 \\
\hline NK. & 63 & 47 & 12 & 24 \\
\hline \multirow[t]{3}{*}{ NP. } & 104 & 86 & 85 & 95 \\
\hline & \multicolumn{4}{|c|}{ Maymen stony loam } \\
\hline & Chamise & $\begin{array}{c}\text { Mt. } \\
\text { mahogany }\end{array}$ & Lettuce & Barley \\
\hline Check. & 31 & 18 & 5 & 26 \\
\hline NPK. & 100 & 100 & 100 & 100 \\
\hline PK. . & 30 & 17 & 27 & 21 \\
\hline NK. & 79 & 84 & 3 & 26 \\
\hline NP. . & 94 & 89 & 87 & 89 \\
\hline
\end{tabular}

* Values for plants without nodules. Plants with nodules would amount to $50 \%$ or more.

ploited in a fertilizing program designed to favor the growth of one type of plant over another. The addition of nitrogen should promote pine and brush, while both nitrogen and phosphorus should swing the balance toward grass. Phosphorus alone would favor the growth of legumes which provide their own nitrogen. If neither phosphorus nor nitrogen was added, then brush plants of the ceanothus type would be favored since they are tolerant of soils low in phosphorus and have nodules which function as nitrogen-fixing organs.

The excessive use or improper choice of fertilizers may have undesirable consequences. A complete fertilizer used on an eroded soil stimulated weed 
growth to a greater extent than the tree crop (Holsoe, 1941 ; McDermott and Burns, 1951). Also to be considered is the effect of fertilizers on the ratio of shoot/root development. This would be of concern in situations involving drought survival or nursery operations prior to transplanting. It has been amply demonstrated that nitrogen, particularly, has the effect of lowering the ratio of root/shoot development (Aldrich-Blake, 1932; Ando and Hukasaku, 1953; Andrews, 1941; Bensend, 1943). This relationship is confirmed by the data presented in this study.

In the matter of explaining plant distribution patterns, the nutritional response of plants offers many possibilities. On a limited scale and in the present instance, the data presented in this study may in some measure explain the virtual exclusion of grasses and the dominance of the pines in the habitat of the phosphate-fixing Salminas soil. On a somewhat larger scale, it may offer a clue to the widespread distribution of the genus ceanothus in the mountains of California.

\section{SUMMARY}

Three upland soils supporting forest or brush were tested for their ability to supply nitrogen, phosphorus, and potassium to plants. The method used was a modified Mitscherlich pot-testing procedure using Romaine lettuce and barley as standard test plants. All three soils were found to be seriously deficient in nitrogen and phosphorus as measured by growth of lettuce and barley. There was no significant response to potassium.

Nutrient responses of seedlings of ponderosa pine, deerbrush, western mountain mahogany, and chamise were determined by the same method.

The pine and brush seedlings, like lettuce and barley, gave strong responses to nitrogen addition on all three soils. With respect to phosphorus, the response of pine and brush was only slight on two of the soils and moderate on the third. The latter soil was shown by a chemical test to be a phosphate-fixing type, while the other two were nonfixing. None of the plants used in these tests gave a significant response to potassium on any of the soils.

A few seedlings of deerbrush, not supplied with nitrogen in the treatments, grew more vigorously than others growing in the same pots. Examination of the root systems after harvesting showed the larger plants to have well-developed nodules on the roots, while the smaller plants had minute nodules.

It was concluded that the differing nutrient responses of these plants could be used in problems of forest and brush manipulation, and applied to questions of plant distribution.

\section{ACKNOWLEDGMENTS}

The authors are indebted to Jack Major, Assistant Professor of Botany, Iniversity of California, Davis, for critically reviewing the manuscript and offering many suggestions. 


\section{LITERATURE CITED}

ALDRICH-BLAKE, R. N.

1932. The influence of nutrition on the relative root and shoot development of forest tree seedlings. Forestry 6:40-52.

ALLEN, R. M.

1953. Release and fertilization stimulate longleaf pine cone crops. Jour. Forestry 51:827.

ANDo, A., and T. HukasakU

1953. The effect on growth of Sugi (Cryptomeria japonica) one-year seedlings of increasing application of fertilizers. Bul. Tokyo Univ. For. No. 44:15-22.

ANDREws, L. K.

1941. Effects of certain soil treatments on the development of loblolly pine nursery stock. Jour. Forestry 39:918-21.

BEADLE, N. C. W.

1954. Soil phosphate and the delimitation of plant communities in eastern Australia. Ecology $35: 370-75$.

Bensend, D. W.

1943. Effect of nitrogen on growth and drought resistence of jack pine seedlings. Minnesota Agr. Exp. Sta. Tech. Bul. 163:1-63.

Boomsma, C. D.

1949. Phosphate for top dressing as a normal plantation operation. Austral. For. 13:108-12.

BotTOMLEY, W. B.

1915. The root nodules of Ceanothus americanus. Ann. Bot. 29:605-10.

Chandler, R. F., JR.

1938. The influence of nitrogenous fertilizer applications upon seed production of certain deciduous trees. Jour. Forestry 36:761-66.

Gessel, S. P., and R. B. WALKer

1956. Height growth response of Douglas fir to nitrogen fertilization. Soil Sci. Soe. Amer. Proc. 20:97-100.

HANSEN, T. S.

1923. Use of fertilizers in a coniferous nursery. Jour. Forestry $21: 732-35$.

Heiberg, S. O., and D. P. White

1951. Potassium deficiency of reforested pine and spruce stands in northern New York. Soil Sci. Soc. Amer. Proc. 15:369-76.

Hellmers, H., J. F. BonNer, and J. M. Kelleher.

1955. Soil fertility. A watershed management problem in the San Gabriel Mountains of southern California. Soil Sci. 80:189-97.

HoLsOE, T.

1941. Fertilizing planting stock on eroded soils. Jour. Forestry 39:69-70.

JenNy, H., J. VlaAmis, and W. E. Martin

1950. Greenhouse assay of fertility of California soils. Hilgardia 20(1):1-8.

МсСомB, A. L., and F. L. KAPEL

1942. Effect of subsoil acidity and fertility on the growth of seedling black locust and green ash. Plant Physiol. 17:7-15.

McDermott, R. E., and P. Y. Burns

1951. Effect of fertilizer on planted pine. Jour. Forestry 49:633.

Quick, Clarence R.

1944. Effects of snowbrush on the growth of Sierra gooseberry. Jour. Forestry 42 : 827-32.

RENNie, Peter J.

1955. The uptake of nutrients by mature forest growth. Plant and Soil. 7:49-95.

RICHARDS, B. N.

1956. The effect of phosphate on slash and loblolly pines in Queensland. Res. Notes For. Serv. (Queensland) 5:1-11. 
Rosendahl, R. O., and C. F. Korstian

1945. Effect of fertilizers on loblolly pine in a North Carolina nursery. Plant Physiol. 20:19-23.

STORIE, R. E., and W. W. WEIR

1953. Soil series of California. The National Press, Palo Alto, California. Pp. 1-128.

TRUOG, EMIL

1930. The determination of the readily available phosphorus of soils. Jour. Amer. Soc. Agron. 22:874-82.

Vlamis, J., E. C. Stone, and C. L. Young

1954. Nutrient status of brushland soils in southern California. Soil Sci. 78:51-55.

WhITE, D. P.

1956. Aerial application of forest fertilizer to coniferous plantations. Jour. Forestry $54: 762-68$. 
The journal Hilgardia is published at irregular intervals, in volumes of about 600 pages. The number of issues per volume varies.

Subscriptions are not sold. The periodical is sent as published only to libraries, or to institutions in foreign countries having pub. lications to offer in exchange.

You may obtain a single copy of any issue free, as long as the supply lasts; please request by volume and issue number from:
Agricultural Publications
Room 22, Giannini Hall
University of California
Berkeley 4, California

The limit to nonresidents of California is 10 separate issues on a single order. A list of the issues still available will be sent on request. 